\title{
Penerapan Metode Tutor Sebaya dapat Meningkatkan Hasil Belajar Pendidikan Agama Hindu dan Budi Pekerti
}

\author{
Ni Luh Adi Palistini ${ }^{1 *}$ iD \\ ${ }^{I}$ SD Negeri 1 Tulamben, Karangasem, Indonesia \\ *Corresponding author: niluhadipalastini67@gmail.com
}

\begin{abstract}
Rendahnya hasil belajar siswa disebabkan karena banyak siswa yang cendurung pasif di kelas dan hanya mendengarkan pembelajaran yang disampaikan oleh guru. Aktivitas siswa hanya cenderung menyimak dan mencatat sehingga berimplikasi pada aktivitas belajar yang tidak optimal. Tujuan penelitian ini adalah untuk menganalisis penerapan metode tutor sebaya untuk meningkatkan hasil belajar pendidikan agama hindu dan budi pekerti. Jenis penelitian ini adalah penelitian Tindakan kelas. Subjek pada penelitian ini sejumlah 37 orang. Metode pengumpulan data pada penelitian ini yaitu observasi, wawancara dan metode tes. Instrumen pada penelitian ini adalah kisi-kisi soal. Teknik analisis data pada penelitian ini adalah analisis deskriptif kuantitatif. Hasil analisis data yaitu Nilai rata-rata siklus I mencapai 76,22 dan siklus II mencapai 81,35. Itu berarti nilai rata-rata dari siklus I ke siklus II telah terjadi peningkatan sebesar 5,13. Kemudian daya serap siswa pada siklus I sebesar 76,22 \% dan siklus II mencapai $81,35 \%$. Berdasarkan data tersebut dari siklus I ke siklus II telah terjadi peningkatan sebesar 5,13\%. Ketuntasan klasikal siswa dari siklus I sebesar 72,97\% telah mengalami peningkatan sebesar $27,03 \%$ menjadi $100 \%$. Sehingga dapat disimpulkan bahwa penerapan metode tutor sebaya efektif meningkatkan hasil belajar siswa pada mata pelajaran Agama Hindu dan Budi Pekerti.
\end{abstract}

Keywords: Tutor Sebaya, Agama Hindu, Budi Pekerti

\section{Abstract}

The low student learning outcomes are due to the fact that many students tend to be passive in class and only listen to the learning delivered by the teacher. Student activities are only tend to listen and take notes so that it has an impact for learning activities that are not optimal. The purpose of this study was to analyze the application of the peer tutoring method to improve learning outcomes of religious education and character. This type of research is classroom action research. The subjects in this study were 37 people. Data collection methods in this study are observation, interviews and test methods. The instrument in this study was the question grid. The data analysis technique in this research is quantitative descriptive analysis. The results of data analysis, namely the average value of the first cycle reached 76.22 and the second cycle reached 81.35. It means that the average value from cycle I to cycle II has increased by 5.13. Then the absorption of students in the first cycle was $76.22 \%$ and the second cycle reached $81.35 \%$. Based on these data, from cycle I to cycle II there has been an increase of $5.13 \%$. Classical mastery of students from the first cycle of $72.97 \%$ has increased by $27.03 \%$ to $100 \%$. So it can be concluded that the application of the peer tutor method is effective in improving student learning outcomes in Hindu Religion and Character subjects.

Keywords: Peer Tutoring, Hindu Religion, Character Subjects

\section{Introduction}

Pembelajaran adalah proses interaksi peserta didik dengan guru dan sumber belajar pada suatu lingkungan belajar. Proses pembelajaran perlu direncanakan, dilaksanakan, dinilai, dan diawasi agar dapat terlaksana secara efektif dan efisien. Proses pembelajaran pada setiap satuan pendidikan dasar dan menengah harus interaktif, inspiratif, menyenangkan, menantang, dan memotivasi peserta didik sehingga dapat mempengaruhi

$\begin{array}{lll}\text { History: } & \text { Publisher: Undiksha Press } \\ \text { Received } & \text { : 24 Juni } 2020 & \text { Licensed: This work is licensed under } \\ \text { Revised } & \text { : 1 Juli } 2020 & \text { a Creative Commons Attribution 3.0 License } \\ \text { Accepted } & \text { : 26 Juli } 2020 & \text { : }\end{array}$


tumbuh kembangnya dan proses belajarnya secara fisik, kognitif, sosial dan emosional (Prasetya et al., 2020; Arif \& Sulistianah, 2019). Sebagai suatu proses kerja sama, pembelajaran tidak hanya menitikberatkan pada kegiatan guru atau siswa saja, akan tetapi guru dan siswa secara bersama-sama berusaha mencapai tujuan pembelajaran yang ditentukan.

Terwujudnya sumber daya manusia yang bermutu dan berkualitas adalah tujuan yang ingin dicapai negara Indonesia terkait dengan kebijakan pemerintah dalam sektor pendidikan. Dengan demikian, ditegaskan bahwa tujuan pendidikan adalah mencerdaskan kehidupan bangsa dan mengembangkan manusia Indonesia seutuhnya dengan jalan mengembangkan potensi peserta didik agar menjadi manusia yang beriman dan bertakwa kepada Tuhan Yang Maha Esa, cerdas, terampil, berbudi pekerti luhur dan cinta tanah air (Widiani et al., 2020; Mulyadin, 2016; Darmansyah, 2014). Salah satu faktor untuk mencapai tujuan itu adalah kegiatan pembelajaran yang diterapkan oleh guru dalam mentransfer konsep pembelajaran. Kegiatan pembelajaran akan melibatkan semua komponen pengajaran, kegiatan pengajaran juga akan menentukan sejauh mana tujuan yang telah ditetapkan dapat tercapai. Kegiatan pembelajaran yang bagaimanapun juga ditentukan dari baik atau tidaknya program pengajaran yang dilakukan dan akan berpengaruh terhadap tujuan yang akan dicapai guru juga sebaiknya memerhatikan perbedaan individual anak didik, yaitu pada aspek biologis, intelektual dan psikologis.

Seorang guru juga dituntut untuk menguasai empat kompetensi, yaitu kompetensi profesional, pedagogi, personal dan sosial (Babuta \& Rahmat, 2019; Damsik, 2017). Kompetensi profesional berkaitan dengan kemampuan guru dalam menguasai materi pelajaran, kompetensi pedagogi mengenai kemampuan dan keterampilan yang dimiliki guru terhadap teori mengajar, kompetensi personal terkait dengan kepribadian guru yang baik, dan kompetensi sosial mengenai kemampuan seorang guru dalam berinteraksi dengan warga sekolah dan masyarakat. Selanjutnya sebagai seorang guru harus betul-betul memahami karakteristik dan keberagaman kecerdasan anak serta mengembangkan kecerdasan tiap anak dengan merancang pembelajaran menyenangkan yang dapat mengakomodasi kecerdasan majemuk. Selain dituntut untuk menguasai empat kompetensi tersebut seorang guru juga dituntut untuk memahami dan mampu menggunakan berbagai macam metode pembelajaran yang bervariasi (Sulfemi, 2019; Mahardika et al., 2017; Theodora, 2016). Dengan diterapkannya metode yang bervariasi siswa diharapkan dapat termotivasi dan suasana pembelajaran tidak membosankan. Jika suasana kelas tidak membosankan maka siswa akan termotivasi untuk belajar dan pada akhirnya tujuan pembelajaran dapat tercapai. Motivasi belajar yang tinggi pada siswa dan tercapainya hasil belajar yang baik inilah yang diharapkan oleh pemerintah pada umumnya dan para pelaku pendidikan pada khususnya. Uraian tersebut merupakan kondisi harapan yang menjelaskan bagaimana seharusnya seorang guru dalam melakukan pembelajaran di kelas serta memahami kondisi yang diharapkan sebagai pendidik. Untuk itu guru harus mampu melaksanakan pembelajaran agar peningkatan mutu pendidikan dapat dicapai sesuai harapan.

Namun kenyataannya, terkadang guru mata pelajaran pendidikan agama Hindu dan Budi Pekerti mengalami kesulitan dalam mengaktifkan siswa secara merata karena kemampuan yang dimiliki oleh setiap siswa tidaklah sama. Oleh karena itu, hanya siswa yang memiliki kemampuan tinggi yang menguasai kelas, sedangkan siswa lainnya pasif, dan persentase siswa pasif lebih banyak daripada siswa yang aktif. Hal itu berdampak pada hasil belajar siswa yang secara klasikal belum memenuhi KKM yang ditargetkan. Hal seperti itu terjadi pada siswa kelas VI Sekolah Dasar Negeri 1 Tulamben. Aktivitas siswa dalam kegiatan pembelajaran cenderung hanya menyimak dan mencatat. Kalau pun ada hal-hal yang kurang jelas, hanya beberapa siswa yang mau bertanya. Pada akhirnya, hal tersebut akan berimplikasi pada aktivitas belajar siswa yang optimal dan hasil belajar siswa sesuai 
harapan. Keberhasilan siswa dalam proses pembelajaran di sekolah ditunjukkan dengan prestasi belajar yang dicapai merupakan akumulasi dari beberapa faktor yang satu dengan yang lainnya saling berkaitan. Proses pembelajaran di sekolah bersifat kompleks, karena di dalamnya terdapat aspek pedagogi, psikologis dan didaktik.

Aspek pedagogi tergambar dari kenyataan di lapangan yang terjadi dalam proses pembelajaran dimana terjadi interaksi yang simultan antara guru dan siswa. Dalam hal ini guru berperan mendampingi siswa dalam perkembangannya menuju kedewasaan melalui proses pembelajaran di kelas. Memahami secara baik tentang ilmu pendidikan tersebut, guru dapat membantu siswa dalam menggali dan mengembangkan potensi yang dimilikinya. Secara psikologis merujuk pada kenyataan bahwa siswa yang belajar di sekolah memiliki kondisi fisik dan psikologis yang berbeda meliputi: intelegensi, bakat, minat, motivasi dan kemampuan kognitif, seperti kemampuan persepsi, ingatan dan berpikir psikologis merujuk pada kenyataan bahwa proses belajar itu sangat bervariasi misalnya ada belajar materi yang mengandung hafalan, ada yang belajar keterampilan motorik, ada belajar konsep, ada belajar sikap dan seterusnya.

Aspek didaktik difokuskan pada pengaturan belajar siswa oleh guru di dalam suatu proses pembelajaran. Ketepatan guru dalam merumuskan tujuan pembelajaran, media, materi, metode dan sistem evaluasi merupakan bagian dalam proses pembelajaran yang memegang peranan penting. Demikian pula kondisi eksternal yang harus diciptakan oleh guru agar mampu mendukung aktivitas pembelajaran yang direncanakan dan dilaksanakan. Hal ini menunjukkan betapa pentingnya peranan guru dalam proses pembelajaran agar siswa dapat mencapai perkembangan yang optimal. Sejalan dengan pemikiran itu hambatan yang muncul dari aspek dapat dikaji dari faktor internal dan eksternal. Kedua aspek ini saling berkaitan satu dengan yang lainnya keterkaitan nya sangat tinggi sehingga membutuhkan pemahaman yang mendalam.

Faktor internal siswa meliputi kondisi fisiologis dan psikologis. Faktor kondisi fisiologis meliputi kesehatan jasmani dan kebugaran fisik, dan kondisi panca indra terutama penglihatan dan pendengaran, sedangkan aspek psikologis meliputi intelegensi, bakat, minat, motivasi dan kemampuan kognitif seperti kemampuan persepsi, ingatan, berpikir dan kemampuan dasar pengetahuan. Sedangkan faktor eksternal siswa dapat berupa: faktor keluarga, sekolah, masyarakat dan lingkungan sosial lainnya. Hambatan dari faktor keluarga dapat berasal dari hubungan orang tua dan anak, cara mendidik anak dan keteladanannya, suasana rumah tangga, dan keadaan ekonomi keluarga. Hambatan dari faktor sekolah dapat berupa cara penyajian pelajaran yang kurang baik, hubungan guru-murid, hubungan teman sebaya, bahan pelajaran, sarana dan prasarana sekolah yang tersedia, kurikulum, waktu belajar, lingkungan belajar dan disiplin sekolah.

Solusi yang dipilih untuk mengatasi masalah rendahnya keaktifan dan hasil belajar siswa adalah dengan penerapan metode tutor sebaya. Metode tutor sebaya adalah sebuah metode pembelajaran yang dilakukan dengan cara memberdayakan kemampuan siswa yang memiliki daya serap tinggi, siswa tersebut mengajarkan materi/ latihan kepada temantemannya yang belum paham (Julianingsih, 2018; Wardani, 2015). Metode tutor sebaya dapat diterapkan di sekolah yang di dalamnya terdapat siswa yang memiliki kepandaian dan rasa percaya diri untuk dapat membantu menjelaskan kepada siswa lain dengan tujuan agar siswa yang merasa malu atau minder bertanya kepada guru dapat bertanya dengan teman sebayanya (Abrianto, 2019; Sari, 2019; Wardani, 2015). Metode tutor sebaya efektif diterapkan karena melalui metode tutor sebaya siswa dapat meningkatkan keterlibatannya dalam kegiatan pembelajaran melalui bimbingan yang diberikan oleh teman sejawatnya. Jika siswa menemukan sendiri pengetahuan itu melalui pembimbingan teman sejawat, siswa akan memiliki kepuasan tersendiri, baik siswa yang memberikan bimbingan maupun siswa yang dibimbing. 
Banyak manfaat yang muncul dalam metode tutor sebaya ini. Bagi siswa yang menjadi tutor, akan lebih meningkatkan kepercayaan dirinya, lebih menguatkan apa yang dia pahami menjadi semakin kuat, menumbuhkan sikap simpati dan saling menolong, menghargai orang lain, dan berlatih mengeluarkan pendapat dalam bentuk lisan, sedangkan bagi siswa yang diajari, dia akan belajar menerima dan menghargai kekurangan dan kelebihan yang dimiliki orang lain, lebih mudah memahami apa yang semula tidak dia pahami dari penjelasan guru karena biasanya proses pembelajarannya akan lebih bersifat kooperatif (Abrianto, 2019; Sari, 2019).

Hasil penelitian yang dilakukan oleh (Abrianto, 2019) menyatakan bahwa penerapan metode tutor sebaya dapat meningkatkan hasil belajar dan motivasi belajar siswa kelas XI MIPA 4 SMA Negeri 1 Ambarawa. Kemudian penelitian yang dilakukan oleh Sari (2019) menyatakan bahwa implementasi tutor sebaya dapat diterapkan dalam mendukung ketuntasan belajar mata pelajaran pendidikan agama Islam materi wudhu dengan hasil yang positif. Penelitian yang dilakukan oleh Julianingsih (2018) menyatakan bahwa melalui strategi pembelajaran dengan tutor sebaya dapat meningkatkan prestasi belajar siswa kelas VI SD Hidayatur Rohman Surabaya tahun ajaran 2016-2017 dalam menyelesaikan soal-soal pada materi pokok bangun datar.

Terdapat perbedaan penelitian ini dengan penelitian sebelumnya seperti penelitian yang dilakukan oleh Abrianto (2019) meneliti mengenai penerapan tutor sebaya untuk meningkatkan hasil belajar dan motivasi belajar. Kemudian penelitian yang dilakukan oleh Sari (2019) meneliti mengenai implementasi tutor sebaya untuk mendukung ketuntasan belajar mata pelajaran Agama Islam. Penelitian yang dilakukan oleh Julianingsih (2018) meneliti mengenai penerapan tutor sebaya untuk meningkatkan pretasi belajar pada materi pokok bangun datar. Berdasarkan jabaran sebelumnya, maka penelitian ini bertujuan untuk menganalisis penerapan metode tutor sebaya untuk meningkatkan hasil belajar Pendidikan Agama Hindu dan Budi Pekerti pada siswa kelas VI sekolah dasar Negeri 1 Tulamben tahun pelajaran 2019/2020.

\section{Materials and Methods}

Rancangan yang digunakan dalam penelitian ini adalah penelitian tindakan kelas (PTK). PTK merupakan penelitian yang bertujuan untuk memberi kontribusi baik sebagai pertimbangan praktis bagi seseorang dalam situasi yang bermasalah di lingkungannya maupun bagi pencapaian tujuan sosial melalui kerjasama kolaboratif dalam kerangka etika yang diterima bersama. Dalam penelitian tindakan kelas terdapat langkah-langkah penelitian yang direncanakan dalam bentuk siklus yang memungkinkan terjadinya kerja kelompok ataupun kerja mandiri secara intensif (Sukardi, 2004: 212). Sesuai dengan hal itu penelitian tindakan kelas itu dilaksanakan secara bertahap dan multi siklus untuk mendapatkan hasil yang terbaik dalam hal ini data yang valid. Setiap siklus yang ada tentunya terdiri atas refleksi awal, kemudian disusul oleh rencana tindakan, pelaksanaan tindakan, observasi/ evaluasi dan refleksi.

Kemmis and Taggart memberikan gambaran umum tentang tahapan penelitian tindakan kelas yang terdiri atas dua siklus, seperti pada Gambar 1. 


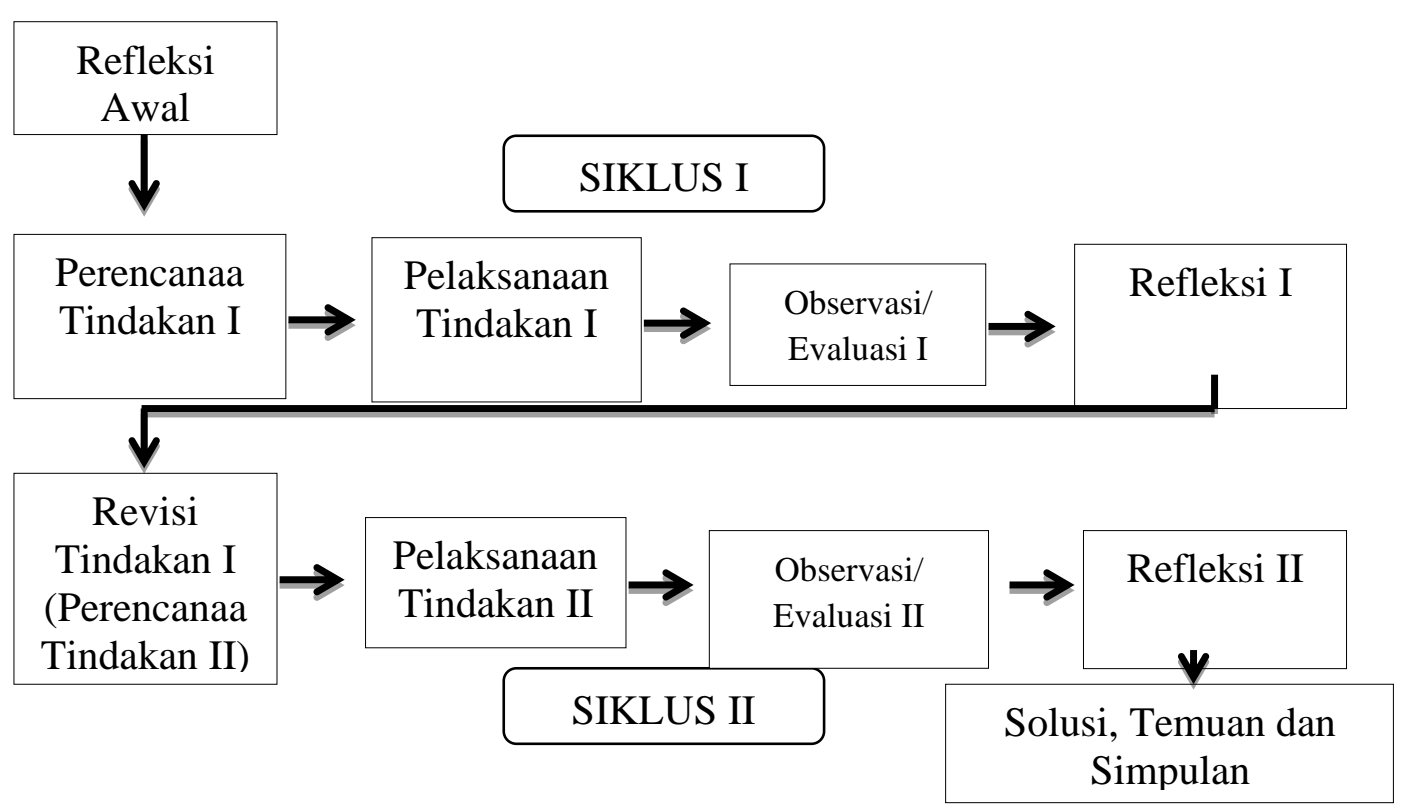

Kemmis and Taggart (dalam Mulyasa, 2009:190).

Gambar 1. Bagan Alur Siklus Penelitian Tindakan Kelas

Dalam penelitian ini, yang menjadi subjek penelitian adalah siswa kelas VI Sekolah Dasar Negeri 1 Tulamben semester I tahun pelajaran 2019/2020, yang berjumlah 37 orang, yakni laki-laki 16 orang dan perempuan 21 orang.

Pengumpulan data pada dasarnya adalah suatu kegiatan operasional agar tindakan yang dilaksanakan masuk pada pengertian penelitian yang sebenarnya. Pengumpulan data di lapangan dengan mempergunakan alat pengumpulan data yang sudah disediakan secara tertulis ataupun dengan alat lain, yang akan dicari di lapangan. Arikunto (2006:118) menguraikan bahwa: "data adalah hasil pencatatan penelitian baik berupa fakta maupun angka" Sedangkan dalam kamus besar bahasa Indonesia diuraikan bahwa: "data adalah keterangan yang benar dan nyata" (Alwi 2005:239). Sementara itu Subagyo (2004:87) menyatakan bahwa: "data adalah semua keterangan seseorang yang dijadikan responden maupun yang berasal dari dokumen-dokumen baik dalam bentuk statistik atau dalam bentuk lainnya guna keperluan penelitian".

Dalam penelitian ini data dikumpulkan dengan menggunakan metode tes. Peneliti lebih tertarik untuk memberikan tes objektif dalam pilihan ganda (multiple choice). Tes objektif yang diberikan sebanyak 20 soal dengan 4 option/ pilihan. Adapun instrument dari metode tes ini berupa kisi-kisi soal dan bentuk soal.

Data yang terkumpul kemudian di analisis untuk bisa menentukan hasil belajar Pendidikan Agama Hindu dan Budi Pekerti pada siswa kelas VI SD Negeri 1 Tulamben semester I tahun pelajaran 2019/2020. Data hasil belajar Pendidikan Agama Hindu dan Budi Pekerti dianalisis secara deskriptif kuantitatif, yaitu dengan menentukan nilai rata-rata hasil belajar (mean), daya serap, dan ketuntasan klasikal belajar siswa dengan rumus sebagai berikut.

1. Untuk menentukan nilai individu dapat menggunakan rumus berikut.

$$
\mathrm{X}=\frac{\sum \text { jawabanbenar }}{\text { jumlahsoal }} \times 100
$$

Keterangan: $X=$ Nilai Individu 
2. Berikut rumus untuk menentukan nilai rata-rata.

$$
\bar{X}=\frac{\sum X}{N}
$$

(Arikunto, 2009: 278)

Keterangan:

$$
\begin{aligned}
\bar{X} & =\text { Nilai rata-rata Prestasi Belajar siswa } \\
\sum X & =\text { Nilai siswa } \\
N & =\text { Jumlah Siswa }
\end{aligned}
$$

3. Berikut rumus untuk menentukan daya serap.

$$
\begin{aligned}
& \bar{X} \\
& \mathrm{DS}=\mathrm{x} 100 \%
\end{aligned}
$$

Skor Maks Keterangan:

DS = Daya Serap

4. Berikut rumus untuk menentukan ketuntasan klasikal.

$$
\underset{\mathrm{KK}}{\sum \mathbf{T}}=\mathrm{x} 100 \%
$$

Keterangan:

$\mathrm{KK}=$ Ketuntasan Belajar Klasikal

$\sum \mathrm{T}=$ Jumlah siswa tunta

$\mathrm{N}=$ Jumlah siswa

\section{Results and Discussion}

Bertolak dari judul penelitian yaitu penerapan metodetutor sebaya untuk meningkatkan hasil belajar Pendidikan Agama Hindu dan Budi Pekerti pada siswa kelas VI Sekolah Dasar Negeri 1 Tulamben, maka secara langsung diadakan pencatatan terhadap hasil belajar siswa kelas VI semester I tahun pelajaran 2019/2020. Hasil belajar yang dimaksud adalah hasil belajar Pendidikan Agama Hindu dan Budi Pekerti yang dalam pembelajaran dengan penggunaan tutor sebaya, serta dilakukan dalam dua siklus pembelajaran yaitu siklus I dan siklus II. Pada masing masing siklus dilaksanakan evaluasi pembelajaran. Pembelajaran yang digunakan adalah penggunaan tutor sebaya yang nantinya diharapkan dapat meningkatkan hasil belajar siswa.

Sedangkan tes hasil belajar menggunakan tes objektif. Tes tersebut berisikan 20 pertanyaan. Data-data yang telah dikumpulkan selanjutnya dianalisis dengan metode-metode yang telah ditetapkan sebelumnya. Dalam pelaksanaan tindakan dilakukan oleh peneliti sekaligus sebagai pengajar.

\section{Hasil penelitian Siklus I}

Pelaksanaan siklus I dilakukan sesuai dengan rencana yang dirancang. Siklus I ini dilaksanakan selama 3 kali pertemuan, yang terdiri atas pelaksanaan tindakan siklus I sebanyak 2 kali pertemuan, dan tes akhir siklus I dilaksanakan dalam 1 kali pertemuan. Siklus I ini dilaksanakan dalam empat tahapan yakni, perencanaan, pelaksanaan tindakan, observasi/ evaluasi dan refleksi.

Sebelum melakukan tindakan, adapun persiapan-persiapan yang perlu dilakukan untuk kelancaran pelaksanaan tindakan. Dalam siklus I, dilakukan beberapa tahap yaitu tahap 
perencanaan tindakan I, pelaksanaan tindakan I, Observasi dan evaluasi I, serta tahap refleksi yang dilaksanakan pada akhir siklus oleh peneliti. Data pada siklus I diolah kemudian disajikan dalam Gambar 1.

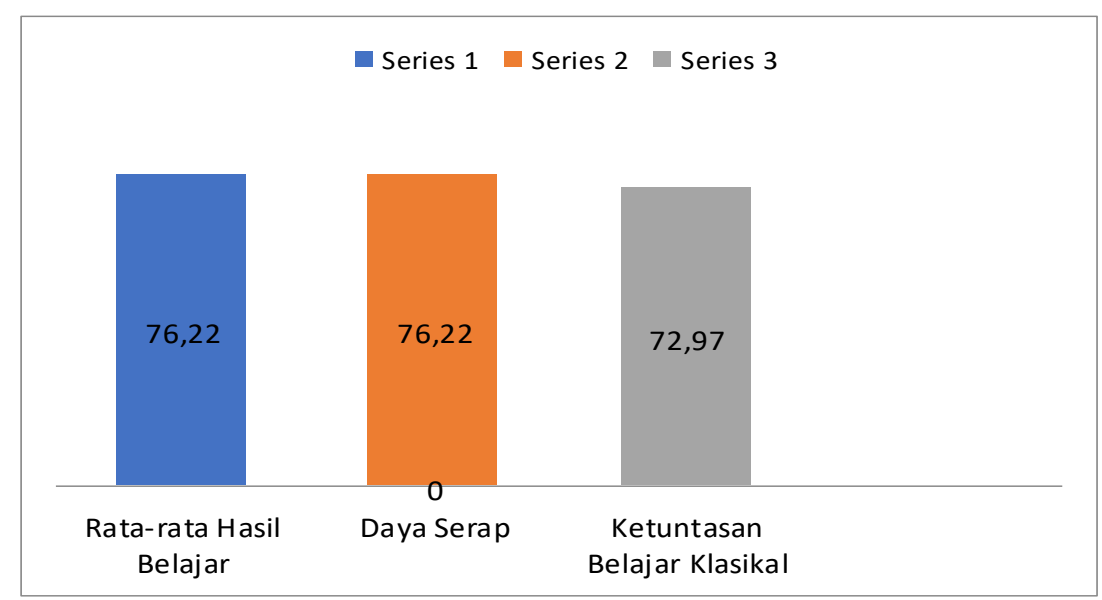

Gambar 1. Grafik Data Hasil Belajar Siklus I

Mencermati pelaksanaan siklus secara keseluruhan, dapat ditegaskan bahwa telah terjadi peningkatan yang cukup signifikan, baik rata-rata hasil belajar, daya serap maupun ketuntasan klasikal. Hasil analisis pada pelaksanaan tindakan siklus I menunjukkan nilai rata-rata yang diperoleh siswa sebesar 76,22 sedangkan daya serap siswa sebesar 76,22\% dan ketuntasan klasikal sebesar 72,97 \%. Hal itu berarti bahwa hasil yang diperoleh oleh siswa pada siklus I masih belum sesuai dengan target yang ditetapkan yaitu ketuntasan klasikal sebesar $85 \%$.

Refleksi ini dilakukan setelah siklus I selesai. Refleksi dilakukan berdasarkan observasi dan evaluasi yang sudah dilakukan. Refleksi ini dilakukan untuk mengetahui kelemahan-kelemahan dan keunggulan-keunggulan pada pelaksanaan tindakan tersebut. Kelemahan-kelemahannya akan dijadikan dasar dalam memperbaiki pelaksanaan pada siklus berikutnya. Sementara itu, keunggulannya akan tetap dipertahankan agar dapat mencapai hasil yang optimal dalam pelaksanaan tindakan tersebut.

Berikut ini akan dibicarakan. Pertama ada beberapa kelemahan yang menyebabkan hasil belajar siswa masih di bawah kriteria keberhasilan. Sesungguhnya, peneliti tidak menemukan kendala yang berarti dalam pelaksanaan penelitian ini, ada beberapa hal yang menjadi fokus perhatian peneliti, yaitu 1) beberapa siswa belum melibatkan diri secara aktif di dalam kelompok, 2) siswa belum mempersiapkan diri secara maksimal untuk mengikuti pembelajaran misalnya beberapa siswa tidak membawa buku catatan dan alat tulis, serta ada beberapa siswa yang belum bisa mengerjakan sendiri pekerjaannya masih hanya meniru pekerjaan temannya tanpa terlibat dalam proses diskusi, 3) siswa kurang berkonsentrasi dengan penjelasan guru, 4) siswa masih belum serius mendengarkan penjelasan tutor sebayanya. Keunggulan dari pelaksanaan siklus I adalah suasana kelas terasa lebih hidup karena siswa yang sebelumnya kurang aktif dalam pembelajaran mulai lebih aktif berkat bantuan dari tutor sebayanya dalam pembelajaran.

Berdasarkan kelemahan-kelemahan tersebut, maka peneliti akan memperbaiki beberapa langkah dalam pembelajaran. Pada tahap pendahuluan, peneliti akan memberikan arahan kepada siswa agar lebih serius dalam belajar. Selain itu, pada tahap kegiatan inti, peneliti akan lebih memberikan pertanyaan kepada siswa yang kurang aktif dalam diskusi agar mereka bisa terlibat secara aktif, serta mengawasi siswa agar tidak hanya meniru pekerjaan temannya, tetapi mulai bisa berkerja mandiri setelah sebelumnya dibimbing oleh 
tutor sebayanya. Terkait dengan masalah kesiapan siswa, peneliti akan memberikan arahan dan mengingatkan siswa agar tidak lupa membawa sarana yang dibutuhkan, misalnya buku latihan, buku pelajaran dan alat tulis lainnya termasuk kesiapan dalam hal materi pembelajaran.

\section{Hasil Penelitian Siklus II}

Sebagaimana halnya dengan pelaksanaan siklus I, pelaksanaan siklus II dilakukan sesuai dengan rencana yang dirancang dan hasil refleksi siklus I. Siklus II dilakukan selama 3 kali pertemuan, yang terdiri atas pelaksanaan tindakan siklus II sebanyak 2 kali pertemuan dan tes akhir siklus II dilaksanakan dalam 1 Kali pertemuan. Siklus II ini dilaksanakan dalam empat tahapan yaitu perencanaan, pelaksanaan tindakan, evaluasi dan refleksi. Hasil Penelitian Siklus II dapat disajikan dalam Gambar 2.

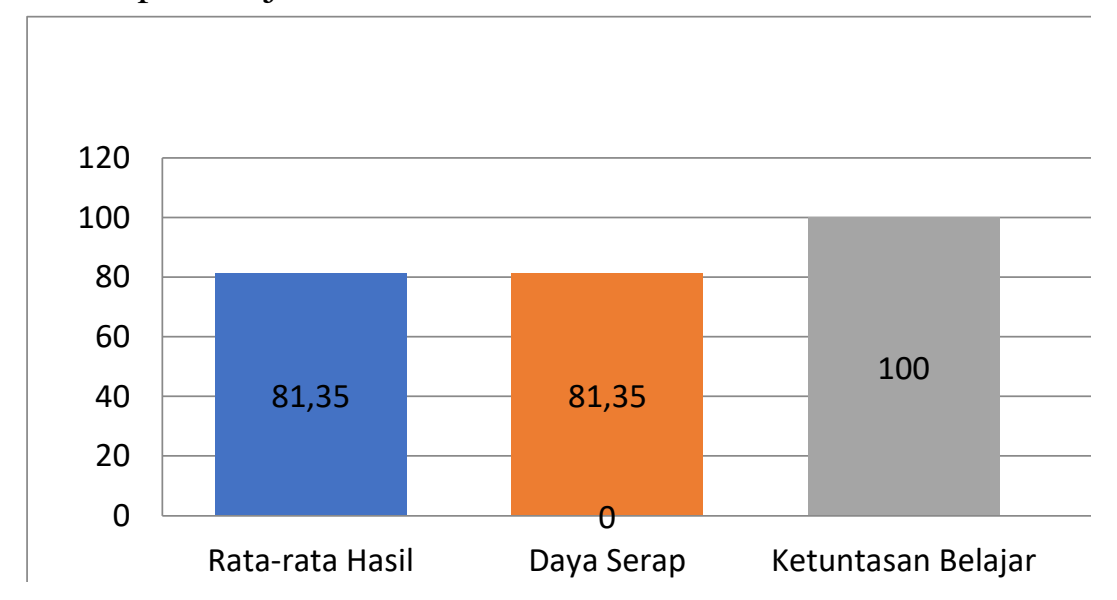

Gambar 2. Grafik Data Hasil Belajar Siklus II

Berdasarkan perhitungan sebelum dilaksanakan tindakan, maka dapat diperoleh hasil dari siklus II, secara klasikal ketuntasannya sudah mencapai $100 \%$. Hal ini menunjukkan bahwa hasil belajar siswa sudah melebihi kriteria yang ditargetkan dalam penelitian ini. Sementara itu nilai rata-rata yang diperoleh siswa pada siklus II sebesar 81,35 dan daya serap sebesar 81,35\%. Apabila dimasukkan kedalam kategori presentase tingkat penguasaan/ daya serap pada table di atas, maka hasil daya serap yang diperoleh siswa kelas VI SD Negeri 1 Tulamben kategori baik. Berdasarkan seluruh hasil belajar diatas berikut tabel perbandingan hasil belajar pra siklus, siklus I dan siklus II. Hal ini dilakukan untuk mengetahui peningkatan hasil belajar siswa kelas VI SD Negeri 1 Tulamben setelah diterapkan metode tutor sebaya. Untuk lebih jelasnya tentang hasil belajar siswa pada siklus I dan siklus II disajikan dalam Tabel 1 dan Gambar 3.

Tabel 1. Rekapitulasi Hasil Belajar, Daya Serap dan Ketuntasan Belajar Pendidikan Agama Hindu dan Budi Pekerti pada Siswa kelas VI.

\begin{tabular}{lllll}
\hline No & Jenis Rekapitulasi Data & Tahapan & Nilai & Peningkatan \\
\hline 111 & Hasil Belajar & Siklus I & 76,22 & 5,13 \\
& & Siklus II & 81,35 & \\
& Daya Serap & Siklus I & $76,22 \%$ & $5,13 \%$ \\
& Ketuntasan Klasikal & Siklus II & $81,35 \%$ & \\
& Siklus I & $72,97 \%$ & 27,03 \\
& Siklus II & $100 \%$ & \\
\hline
\end{tabular}




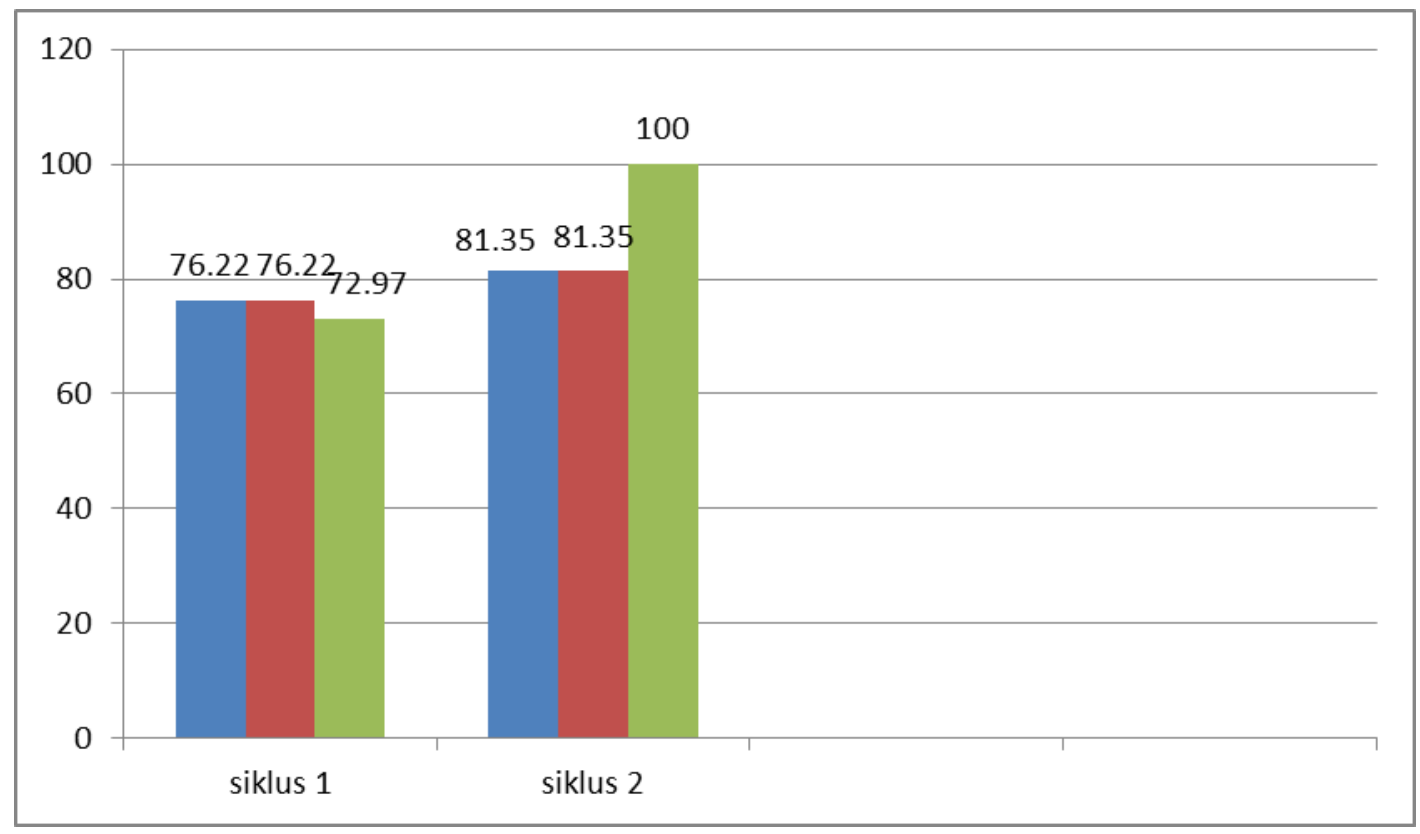

Gambar 3. Grafik Rekapitulasi Hasil Belajar Siklus I dan Siklus II

Pada Siklus II terjadi peningkatan rata-rata hasil belajar siswa dari 76,22 menjadi 81,35 dan daya serap juga mengalami peningkatan dari 76,22 \% menjadi $81,35 \%$, sedangkan ketuntasan belajar klasikal dari 72,97 \% meningkat menjadi 100\%. Meskipun pada evaluasi siklus II semua siswa tuntas, karena nilai hasil belajar yang di peroleh sudah sesuai dengan kiteria ketuntasan belajar tetapi masih perlu ditingkatkan lagi. Berdasarkan hasil yang diperoleh berarti bahwa kriteria keberhasilan yang ditetapkan peneliti sudah tercapai.

Langkah awal sebelum pelaksanaan tindakan adalah melakukan observasi. Observasi awal dilakukan dengan mengkaji hasil ulangan harian siswa. Ulangan harian yang dilaksanakan mencakup beberapa indikator yang berkaitan dengan materi. Hasil kajian tersebut menunjukkan bahwa hanya ada beberapa siswa yang tuntas dalam pembelajaran, sedangkan sebagian besar siswa yang lain memperoleh nilai di bawah kriteria ketuntasan minimal. Sehingga siswa yang tuntas ini ditunjuk sebagai tutor sebaya. Berdasarkan hasil penelitian menunjukkan bahwa rata- rata hasil belajar siswa kelas II mengalami perubahan yang cukup signifikan mulai dari pra siklus hingga pelaksanaan siklus II. Nilai rata-rata hasil belajar siklus I sebesar 76,22 dan siklus II sebesar 81,35. Itu berarti nilai-rata-rata dari siklus I ke siklus II telah terjadi peningkatan sebesar 5,13. Kemudian daya serap siswa juga mengalami peningkatan dari siklus I ke siklus II. Daya serap siswa siklus I sebesar 76,22\% dan pada siklus II sebesar $81,35 \%$. Berdasarkan data siklus I dengan siklus II mengalami peningkatan sebesar 5,13\%.

Tidak hanya nilai rata-rata siswa dan daya serap saja yang mengalami peningkatan, ketuntasan klasikal juga meninngkat. Pada siklus I terdapat 27 orang siswa yang tuntas dan 10 orang siswa yang tidak tuntas. Selanjunya pada siklus II semua siswa tuntas. Meskipun ada beberapa siswa yang nilainya sama dengan kriteria ketuntasan belajar. Berdasarkan data tersebut ketuntasan klasikal siswa pada siklus I sebesar $72,97 \%$ dan pada siklus II sebesar $100 \%$. Oleh karena itu, dari siklus I ke siklus II terjadi peningkatan sebesar 27,03\%. Peningkatan nilai rata-rata, daya serap, dan ketuntasan klasikal dari siklus I dengan siklus II karena penerapan metode tutor sebaya pada siklus II lebih optimal. Perbaikannya adalah pada tahap pendahuluan, peneliti memberikan arahan kepada siswa agar lebih serius dalam memperhatikan penjelasan guru, dan pada tahap kegiatan inti peneliti mengganti tutor sebaya yang kurang kompeten dan lebih fokus memberikan perhatian kepada siswa yang kurang 
aktif dalam proses diskusi dan kepada siswa yang masih suka meniru pekerjaan temannya. Terkait dengan masalah kesiapan siswa, peneliti juga memberikan motivasi dan arahan kepada siswa agar tidak lupa membawa alat pelajaran. Oleh karena itu dalam penerapan metode tutor sebaya hendaknya dilengkapi dengan adanya perhatian yang lebih fokus terhadap siswa dan pemilihan siswa yang menjadi tutor sebaya juga harus tepat.

Banyak manfaat yang muncul dalam metode tutor sebaya ini. Bagi siswa yang menjadi tutor, akan lebih meningkatkan kepercayaan dirinya, lebih menguatkan apa yang dia pahami menjadi semakin kuat, menumbuhkan sikap simpati dan saling menolong, menghargai orang lain, dan berlatih mengeluarkan pendapat dalam bentuk lisan, sedangkan bagi siswa yang diajari, dia akan belajar menerima dan menghargai kekurangan dan kelebihan yang dimiliki orang lain, lebih mudah memahami apa yang semula tidak dia pahami dari penjelasan guru karena biasanya proses pembelajarannya akan lebih bersifat kooperatif (Abrianto, 2019; Sari, 2019).

Hasil penelitian yang dilakukan oleh Abrianto (2019) menyatakan bahwa penerapan metode tutor sebaya dapat meningkatkan hasil belajar dan motivasi belajar siswa kelas XI MIPA 4 SMA Negeri 1 Ambarawa. Kemudian penelitian yang dilakukan oleh Sari (2019) menyatakan bahwa implementasi tutor sebaya dapat diterapkan dalam mendukung ketuntasan belajar mata pelajaran pendidikan agama Islam materi wudhu dengan hasil yang positif. Penelitian yang dilakukan oleh Julianingsih (2018) menyatakan bahwa melalui strategi pembelajaran dengan tutor sebaya dapat meningkatkan prestasi belajar siswa kelas VI SD Hidayatur Rohman Surabaya tahun ajaran 2016-2017 dalam menyelesaikan soal-soal pada materi pokok bangun datar.

Terdapat perbedaan penelitian ini dengan penelitian sebelumnya seperti penelitian yang dilakukan oleh Abrianto (2019) meneliti mengenai penerapan tutor sebaya untuk meningkatkan hasil belajar dan motivasi belajar. Kemudian penelitian yang dilakukan oleh Sari (2019) meneliti mengenai implementasi tutor sebaya untuk mendukung ketuntasan belajar mata pelajaran agama Islam. Penelitian yang dilakukan oleh Julianingsih (2018) meneliti mengenai penerapan tutor sebaya untuk meningkatkan pretasi belajar pada materi pokok bangun datar. Berdasarkan jabaran sebelumnya, maka penelitian ini bertujuan untuk menganalisis penerapan metode tutor sebaya untuk meningkatkan hasil belajar pendidikan agama Hindu dan budi pekerti pada siswa kelas VI sekolah dasar Negeri 1 Tulamben tahun pelajaran 2019/2020.

\section{Conclusion}

Berdasarkan hasil penelitian dan pembahasan hasil, maka dapat disimpulkan bahwa penerapan metode tutor sebaya dalam pembelajaran Pendidikan Agama Hindu dan Budi Pekerti di kelas VI Sekolah Dasar Negeri 1 Tulamben dapat meningkatkan hasil belajar siswa. Hal ini terbukti rata-rata hasil belajar, daya serap siswa, dan ketuntasan klasikal siswa pada siklus I sampai siklus II yang meningkat.

\section{References}

Abrianto, O. R. (2019). Penerapan Metode Tutor Sebaya Untuk Meningkatkan Hasil Belajar Dan Motivasi Belajar Siswa Pada Materi Trigonometri Kelas XI Mipa 4 SMA Negeri 1 Ambarawa. Satya Widya, 35(1), 62-74. https://doi.org/10.24246/j.sw.2019.v35.i1.p6274.

Arif, M., \& Sulistianah, S. (2019). Problems in 2013 Curriculum Implementation for Classroom Teachers in Madrasah Ibtidaiyah. Al Ibtida: Jurnal Pendidikan Guru MI, 6(1), 110-123. http://dx.doi.org/10.24235/al.ibtida.snj.v6i1.3916.

Babuta, A. I., \& Rahmat, A. (2019). Peningkatan Kompetensi Pedagodik Guru Melalui 
Pelaksanaan Supervisi Klinis Dengan Teknik Kelompok. Al-Tanzim: Jurnal Manajemen Pendidikan Islam, 3(1), 1-28. https://doi.org/10.33650/al-tanzim.v3i1.496.

Damsik, M. G. (2017). Penerapan Supervisi Klinis untuk Perbaikan Kegiatan Belajar Mengajar di Madrasah Aliyah Paradigma Palembang. Conciencia, 17(2), 46-57.

Darmansyah, D. (2014). Teknik penilaian sikap spritual dan sosial dalam pendidikan karakter di sekolah dasar 08 Surau Gadang Nanggalo. Al-Ta'Lim, 21(1). https://doi.org/10.15548/jt.v21i1.67.

Julianingsih, D. (2018). Upaya Meningkatkan Prestasi Belajar Siswa Matematika Melalui Strategi Pembelajaran Tutor Sebaya Dalam Penguasaan Bangun Datar Kelas VI SD Hidayatur Rohman Surabaya. Edumatika : Jurnal Riset Pendidikan Matematika, 1(1). https://doi.org/10.32939/ejrpm.v1i1.219.

Mahardika, I. M. A. Y., Agung, A. A. G., \& Rendra, N. T. (2017). Pengaruh model pembelajaran scramble terhadap hasil belajar bahasa Indonesia siswa kelas III. EJournal PGSD Universitas Pendidikan Ganesha, 5(2), 1-11. https://doi.org/http://dx.doi.org/10.23887/jjpgsd.v5i2.10888.

Mulyadin, M. (2016). Implementasi kebijakan pembelajaran tematik terpadu Kurikulum 2013 di SDN Kauman 1 Malang dan SD Muhammadiyah 1 Malang. Jurnal Edutama, 3(2), 31-48. http://ejurnal.ikippgribojonegoro.ac.id/index.php/JPE/article/view/35/35.

Prasetya, S. P., Segara, N. B., \& Imron, A. (2020). Effectiveness Of Outdoor Learning Optimization Program In Learning Social Studies. JPI (Jurnal Pendidikan Indonesia), 9(2), 314. https://doi.org/10.23887/jpi-undiksha.v9i2.19160.

Sari, E. (2019). Implementasi Tutor Sebaya dalam Ketuntasan Sekolah Belajar Materi Berwudhu Kelas Tingkat Sekolah Dasar. Al-Iltizam: Jurnal Pendidikan Agama Islam, 4(1). https://doi.org/http://dx.doi.org/10.33477/alt.v4i1.772.

Sulfemi, W. B. (2019). Model Pembelajaran Kooperatif Mind Mapping Berbantu Audio Visual Dalam Meningkatkan Minat, Motivasi Dan Hasil Belajar IPS. Jurnal PIPSI (Jurnal Pendidikan IPS Indonesia), 4(1), 13. https://doi.org/10.26737/jpipsi.v4i1.1204.

Theodora, B. D. (2016). Pengaruh Keterampilan Mengajar Guru Terhadap Hasil Belajar Siswa Sma Se-Kota Malang Yang Di Kontrol Dengan Variasi Sumber Belajar. Journal of Accounting and Business Education, 2(4). https://doi.org/10.26675/jabe.v2i4.6079.

Wardani, U. K. (2015). Peningkatan minat dan hasil belajar memproses buku besar melalui pembelajaran tutor sebaya pada kelas x akuntansi $3 \mathrm{smk} n$ i salatiga semester genap tahun 2013/2014. Jurnal Pendidikan Ilmu Sosial, 25(2). https://doi.org/https://doi.org/10.2317/jpis.v25i2.1537.

Widiani, A. A. O. V., Lasmawan, W., \& Suarni, K. (2020). Pengaruh model pembelajaran TGT berbantuan permainan tradisional terhadap sikap sosial dan hasil belajar PKn siswa. PENDASI: Jurnal Pendidikan Dasar Indonesia, 4(1), 13-22. https://doi.org/DOI: https://doi.org/10.23887/jpdi.v4i1. 